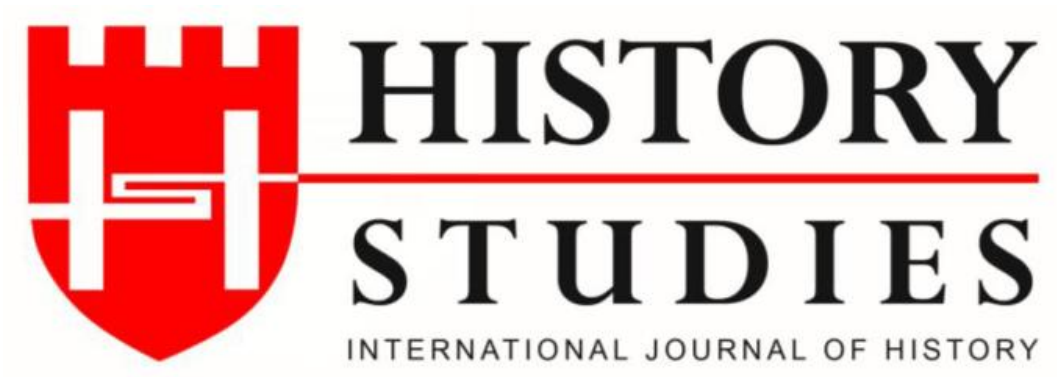

ISSN: 13094173 (Online) 1309 - 4688 (Print)

Volume 12 Issue 4, August 2020

DOI Number: 10.9737/hist.2020.906

Araştırma Makalesi

Makalenin Geliş Tarihi: 13.05.2020 Kabul Tarihi: 16.06.2020

Atıf Künyesi: İsrafil Karataş, “12 Mart Müdahalesine Giden Yolda Cumhurbaşkanı'na Gelen Şikâyet ve Öneriler", History Studies, 12/4, Ağustos 2020, s. 1955-1971.

\title{
12 Mart Müdahalesine Giden Yolda Cumhurbaşkanı'na Gelen Şikâyet ve Öneriler
}

Complaints and Suggestions to the President during the March 12 Military Intervention

\author{
Dr. İsrafil Karatas \\ ORCID No: 0000-0003-4940-9344 \\ Alanya Alaaddin Keykubat Üniversitesi
}

\begin{abstract}
Öz: 1970 yllının başlarında, Türkiye'de birkaç yıldan beri var olan anarşinin boyutu hükümet ve devlet açısından tehlikeli bir hal almaya başlamıştır. Toplumun her kesiminde askeri bir müdahale beklentisinin arttığı bu yıldan itibaren yaşanan anarşiye kayıtsız kalamayan bazı siyasi partiler, Meclis üyeleri ve sivil toplum örgütleri Cumhurbaşkanı Cevdet Sunay'a şikâyet ve çözüm önerilerini içeren bir takım başvurularda bulunmuşlardır. $\mathrm{Bu}$ çalışmanın amacı, bu başvuruları temel alarak 12 Mart 1971 Müdahalesi'ne giden günlerde olaylar karşısında söz konusu bu siyasi partilerin, Meclis üyelerinin ve sivil toplum örgütlerinin tavır ve tutumlarının ne olduğunu ortaya koymak ve en önemlisi de şikâyet ve çözüm önerilerini incelemektir. Çalışmada, temel olarak Cumhurbaşkanlığı Cevdet Sunay Arşivi’ne ait belgelerle birlikte resmi yayınlar, süreli yayınlar ve telif eserler kullanılmıştır.
\end{abstract}

Anahtar Kelimeler: 12 Mart Müdahalesi, Muhtıra, Adalet Partisi, Öneri, Cevdet Sunay.

Abstract: In the beginning of 1970, the extent of the anarchy that had existed for several years in Turkey began to turn into a dangerous situation for the state and government. Some political parties, members of the Parliament and, non-governmental organizations who could not remain indifferent to the anarchy experienced during that year, when the expectation of a military intervention increased in every part of the society, made a lot of applications including complaints and solutions to President Cevdet Sunay. The purpose of this study is to reveal the attitudes and attitudes of these political parties, members of the Parliament and, non-governmental organizations in the face of the events in the days leading up to the March 12, 1971 Intervention, and above all to examine their complaints and solutions. In this study, official publications, periodicals and, copyrighted works were used along with the documents belonging to the Presidency of Cevdet Sunay's Archive.

Keywords: March 12 Intervention, Memorandum, Justice Party, Proposal, Cevdet Sunay. 


\section{Giriş}

1961 Anayasası birçok özgürlükleri beraberinde getirmiştir. Anayasa'nın garanti ettiği düşünce, ifade, örgütlenme ve serbest yayın yapma gibi özgürlükler sayesinde ${ }^{1}$ direniş ve eylemleri nedeniyle bazen hükümetleri zor duruma düşürebilecek öğrenciler ve işçiler gibi iki yeni dinamik güç ortaya çıkartmıştır. ${ }^{2} 1960$ 'lı yıllarda işçiler, başlattıkları sendikal hareketlerle siyasallaşmışlardır. Partiler üstü politikayı savunan Türk-İş’ten ayrılan bazı işçiler, 1967'de Devrimci İşçi Sendikaları Konfederasyonu'nu (DİSK) kurmuşlardır. DİSK ile birlikte, bir memur sendikası olan Türkiye Öğretmenler Sendikası (TÖS) da sol eylemlere ve hareketlere büyük oranda destek vererek siyasal mücadelede etkin hale gelmişlerdir. Bu sendikalar, üyelerinin ekonomik ve sosyal çıkarlarını korumak için sendikal mücadele yürütmekten daha ziyade işçi sınıfının muhtemel iktidarını kurmanın çalışmasını yürütmüşlerdir. ${ }^{3}$

Solun yasal yoldan iktidara gelmesi için 1961 yılında kurulan Türkiye İşçi Partisi (TIP) ile ittifak halinde hareket eden DISSK'in, ${ }^{4} 1970$ yılının başlarına gelindiğinde üye sayısını 800 bin gibi yüksek bir sayıya çıkartması üzerine Hükümet, sendikanın daha fazla örgütlenmesini engellemek adına Haziran 1970'te Meclis'ten bir yasa çıkartmıştır. ${ }^{5}$ Çıkan yasayı protesto etmek amaciyla Sendika, İstanbul-Marmara bölgesinde 15-16 Haziran 1970 tarihlerinde o güne kadarki en büyük işçi eylemini gerçekleştirmiştir. Ortaya çıkan düzensizliği Hükümet, İstanbul ve Kocaeli'nde sıkıyönetim ilan etmek, askeri güç kullanmak ve bütün ulaşım yollarını kesmek suretiyle durdurabilmiştir. ${ }^{6}$ Büyük çaptaki bu eylemi Türk-İş yönetimi bir komünist tahriki olarak nitelerken, Hükümet ve bazı basın organları bir ayaklanma girişimi olarak lanse etmişlerdir. ${ }^{7}$ Hizla yükselen ve giderek büyüyen yasal sol hareketlere karşıl1k devletin yeşil 1 şık yaktığ1 Milliyetçi Hareket Partisi'nin etrafında toplanan gençlik ve meslek örgütleri de eylemli mücadeleye geçmiştir. Bu anlamda DİSK'e karşı 23 Haziran 1970 tarihinde, 15-16 Haziran Olayları'ndan hemen sonra, Milliyetçi İşçi Sendikaları Konfederasyonu (MISK) kurulmuştur. Sınıf sendikacılığı ile bir ilişkisi olmayan, devlete bağlı ve sermaye kesimleriyle organik ilişkisi bulunan sendikanın, geniş işçi hareketi içinde herhangi bir ağırlığı olmamıştır. ${ }^{8}$

İşçilerin yanı sıra 1960'lı yıllarda öğrenciler yani gençler de yaptıkları direniş ve eylemlerle hükümetleri zor duruma düşürmüşlerdir. 1965 yllına gelindiğinde bir şekilde devletin gözetimi ve koruması altında olan öğrenci teşekküllerinin dışında sosyalist, sol eğilimli Fikir Kulüpleri Federasyonu (FKF) kurulmuştur. Kurucuları TİP'li veya TİP sempatizanı olan Federasyon, ${ }^{9}$ çok geniş öğrenci kesimini siyasallaştırmıştır. FKF'den Türkiye Devrimci Gençlik Federasyonu'na (Dev-Genç) dönüşecek olan bu sol öğrenci oluşumu, ilk önce dünyada ortaya çıkan 1968 öğrenci hareketlerinin Türkiye'de de yaygınlaşmasında büyük etkin rol oynamıştır. İlk başlarda yetersiz eğitim sistemine bir tepki olarak ortaya çıkıp gelişen 1968 öğrenci olayları

\footnotetext{
${ }^{1}$ Feroz Ahmad, Demokrasi Sürecinde Türkiye (1945-1980), 4.Bask1, Hil Yayınları, İstanbul 2010, s. 236-237.

${ }^{2}$ Hikmet Özdemir, "Siyasi Tarih (1960-1980)", Türkiye Tarihi 4 Çağdaş Türkiye 1908-1980, Yayın Yönetmeni: Sina Akşin, 12. Basım, Cem Yayınevi, İstanbul 2013, s. 259.

${ }^{3}$ Davut Dursun, 12 Mart Darbesi: Hatıralar, Gözlemler, Düşünceler, Şehir Yayınları, İstanbul 2003, s. 27.

${ }^{4}$ William Hale, Türkiye'de Ordu ve Siyaset, Çeviri: Ahmet Fethi, Alfa Yayınlar, İstanbul 2014, s. 255. DİSK, bu süreçte ekonomik taleplerin ancak siyasi eylemlerle kazanılabileceğini ileri sürerek TiP'i desteklemiştir. Feroz Ahmad, Modern Türkiye'nin Oluşumu, 9. Basım, Kaynak Yayınları, İstanbul 2011, s. 171.

${ }^{5}$ Suavi Aydın-Yüksel Taşkın, 1960’tan Günümüze Türkiye Tarihi, İletişim Yayınları, İstanbul 2014, s. 191-192.

${ }^{6}$ Tevfik Çavdar, Türkiye'nin Demokrasi Tarihi 1950'den Günümüze, 5. Bask1, İmge Kitabevi, Ankara 2013, s. 163, Ahmad, Modern Türkiye'nin Oluşumu, s. 174, Hale, age, s. 225.

${ }^{7}$ Çavdar, age, s. 174.

${ }^{8}$ Aydın-Taşkın, age, s. 197-198.

${ }^{9}$ Çavdar, age, s. 182.
} 
ise, daha sonra iç ve dış gelişmelerin etkisiyle üniversite ve eğitim alanı dışında Türkiye'nin bağımsızlığı ve kalkınma modeli gibi mücadele alanlarına kaymıştır. ${ }^{10}$

1968 yazında üniversitelerdeki boykot ve işgaller tırmanışa geçmiştir. ${ }^{11}$ Tırmanışa geçen sol eylemler karşısında sağ cenahta bir toparlanma ve sola karşı saldırıya geçme durumu ortaya çıkmıştır. ${ }^{12}$ Ülkü ocaklarına bağlı olarak askeri eğitim verilen Komando Kampları kurulmuş ve bunlar sokaklarda, üniversitelerde yükselemeye başlayan sol gençlik hareketinin karşısına çıkartılmıştır. ${ }^{13}$ Yine aynı şekilde İslamcı akımlar da bu süreçte ön plana çıkmaya başlamıştır. 19 Mayıs 1968 tarihinde Dolmabahçe Camii'nde gösteri niteliğinde ilk toplu namaz kılınmıştır. Bugün Gazetesi aracılığıyla İslamcı akımın siyasal bir niteliğe bürünmeye başlandığı görülmektedir. Yine son olarak 1968 yılı içerisinde Necmettin Erbakan'ın başını çektiği grubun Odalar Birliği'nde kazandığı etkinlik de İslamcı muhalefetin artık harekete geçtiğini gösteren önemli işaretlerden birisi olmuştur. ${ }^{14}$

Başbakan Süleyman Demirel ise bütün bu sağ-sol çatışmalar karşısında sola karşı mücadele etmenin yanı sıra sola karşı örgütlenmiş olan yasadışı sağ oluşumları görmezden gelerek bir yerde onları desteklemiştir. Bu anlamda Demirel, tüm uyarılara rağmen Komando Kampları'nı kapatmaya yanaşmamıştır. ${ }^{15}$ Öte yandan Demirel, bu tarihten itibaren çıkan olayların sorumlusu olarak 1961 Anayasası'nı göstermiş ve Anayasa'yı suçlamıştır. Anayasa'nın derhal değiştirilmesini isteyen Demirel'e göre, 1961 Anayasası "gereğinden fazla özgürlük" barındırıyordu. ${ }^{16}$ Cumhuriyet Halk Partisi (CHP) ise sorunun Anayasa'dan değil, anayasayı uygulamaktan kaçınan iktidar partisinden kaynaklanmakta olduğunu ve iktidarın değişmesi halinde bu sorunun ortadan kalkacağını öne sürmüştür. ${ }^{17}$ Böylece sokaklardaki çatışma, Meclis'e de sirayet etmişsir.

1969 Genel Seçimleri'ne kadar geçen süre zarfında öğrenci eylemleri üniversite kampüslerinden sokaklara taşmaya başlamıştır. Temmuz 1968 'de Tï'e ve FKF'ye bağlı gençler, 6. Filo'nun İstanbul'u ziyaretini protestosu ederken çıkan olaylarda 2 genç öldürülmüştür. Şubat 1969 'da 6. Filo’yu protesto etmek isteyen öğrenci ve işçilerle, dönemin sağc1 gazeteleri Bugün ve Sabah tarafından galeyana getirilen sağcı kitle arasında tarihe "Kanlı Pazar" olarak geçecek olan olumsuz olaylar meydana gelmiştir. Yine 2 kişinin öldürüldüğü bu olaylardan sonra sağ-sol arasındaki husumet, derinleşmiştir. ${ }^{18} 1969$ yılının başlarında da Ankara'nın ABD Büyükelçiliği'ne atanmış olan Kommer'in ODTÜ'yü ziyareti sırasında arabasının sol eğilimli öğrenciler tarafınca yakılmas ${ }^{19}$ ülkedeki huzursuzluğu artıran bir diğer olaydı. Anarşi sadece şehirlerde değil, aynı zamanda kırsal alanda da vardı. Kırsalda toprak işgalleri, mitingler şeklinde kendisini gösteren bu eylem ve direnişlerde üreticilere en büyük destek sol eğilimli gençlerden gelmiştir. ${ }^{20}$ Olayların yönünü tehlikeli başka bir tarafa çekecek olan en büyük gelişme ise 1969 Genel Seçimleri’nin sonuçlarıdır.

\footnotetext{
${ }^{10}$ Özdemir, agm, s. 260.

${ }^{11}$ Hikmet Çetinkaya, 68'den 78'e Sancılı Yıllar Kuşatılmış Sokaklar, 6. Basım, Günizi Yayıncılık, İstanbul 2006, s. 45.

${ }^{12}$ Cem Eroğul, "Çok Partili Düzenin Kuruluşu: 1945-1971”, Geçiş Sürecinde Türkiye, Derleme: Irvın C. Schınk ve

E. Ahmet Tonak, Bask1: 6, Belge Yayınları, İstanbul 2013, s. 233.

${ }^{13}$ Aydın-Taşkın, age, s. 158.

${ }^{14}$ Eroğul, agm, s. 233-234.

${ }^{15}$ Ahmad, Demokrasi Sürecinde Türkiye, s. 253; Eroğul, agm, s. 234.

${ }^{16}$ Ahmad, Demokrasi Sürecinde Türkiye, s. 253-254.

${ }^{17}$ Dursun, age, s. 17.

${ }^{18}$ Aydın-Taşkın, age, s. 158.

${ }^{19}$ Çavdar, age, s. 186.

${ }^{20}$ Çavdar, age, s. 187.
} 
Meşru yoldan yani seçimle iktidara gelmeyi savunan TiP'in ${ }^{21} 1969$ Genel Seçimler öncesinde milli bakiye sistemini kaldıran bir değişiklikle önü kesilmiştir. 1965 Genel Seçimleri'nde 15 milletvekili çıkartan Tï, 1969 Genel Seçimleri'nin sonucunda bu yüzden sadece 2 milletvekili çıkartabilmiştir. ${ }^{22}$ Dolayısıyla TiP, sistem dışına itilmiştir. ${ }^{23}$ Seçim sonuçlarına göre, Adalet Partisi (AP) iktidarını sürdürmeye hak kazanmıştır. Bu durum daha önce solcular arasında var olan darbeci yöntemleri savunanlar yani parlamentarizmi küçümseyenler için önemli bir dayanak oluşturmuştur. Demokratik yöntemlere güveni sarsılmış, düzen değişikliğinin parlamento ve seçimle gerçekleştirilebileceğinden ümidini kesen bu sol, demokrasi dışı yolların denenmesi gerektiği fikrini daha güçlü savunmaya başlamıştır. ${ }^{24}$ Savunmakla da kalmayarak bu noktadan sonra harekete geçmişlerdir. Dev-Genç içerisinden 1970 yllında THKO (Türkiye Halk Kurtuluşu Ordu) ve THKP-C (Türkiye Halk Kurtuluş Partisi-Cephesi) isimli iki silahlı eylem yapacak örgüt çıkmıştır. Kan dökülmesinin normal hale geldiği günlerde ${ }^{25}$ silahlı mücadeleye başvurmuş olan THKO üyeleri, Filistin'e giderek buradaki kamplarda gerilla eğitimi almaya başlamışlardır. ${ }^{26} 1971$ yılının başlarından itibaren ise anarşi olaylarının rengi değişmeye başladığı gözlemlenmektedir. THKO örgütü kendisine maddi destek bulmak amacıyla ilk banka soygunlarına başlamıştır. Ocak 1971'de İş Bankası'nın Ankara Emek Şubesi soyulmuştur. ${ }^{27}$ Kısacası 1971 yılının Ocak ayına gelindiğinde Türkiye, tam bir kaos ortamı içerisine girmiştir. Üniversiteler tam anlamıyla işlevlerini kaybetmiştir. Latin Amerikan şehir gerillalarını taklit eden örgüt üyeleri, banka soymaya, Amerikan görevlilerini kaçırmaya ve onların yerlerine saldırmaya başlamışlardır. Hükümet' $i$ eleştiren profesörler de bir şekilde "neofaşist militanlar" tarafından cezalandırılmıştır. Fabrikaların da grevde olduğu bu süreçte önceki dönemlere göre çok fazla iş gücü kaybedilmiştir. İslami hareket kanadında yer alan Milli Nizam Partisi de daha da saldırganlaşarak Atatürk'ü ve Kemalizm'i, orduyu kızdıracak şekilde reddetmeye başlamıştır. ${ }^{28}$

1969 Genel Seçimleri sonrasında solun bir kısmı bu şekilde yasal olmayan eğilimler gösterirken, sağda ise büyük bölünmeler yaşanmıştır. Başbakan Demirel, seçimlerden sonra kurduğu kabinede eski DP unsurlarını tamamen dışarıda bırakınca, parti içerisinde Demirel'e karşı büyük bir meydan okuma baş göstermiştir. Kabine'nin bütçe tasarısında karşı oy kullanan parti içindeki muhalifler, aynı zamanda kardeşlerine büyük krediler sağlamak için siyasi nüfusunu kullandığına dair kanıtlanamayan suçlamalarda bulunarak Demirel'in liderliğine karş1 çıkmışlardır. $\mathrm{Bu}$ muhalefet sonucunda partiden atılan AP'liler, Ferruh Bozbeyli'nin başkanlığında 18 Aralık 1970 tarihinde Demokratik Parti' yi kurmuşlardır. ${ }^{29}$ Öte yandan Ocak 1970'de Milli Nizam Partisi'nin de kurulmuş olmass ${ }^{30}$ sağdaki parçalanmayı daha da arttırmıştır. Böylece, Demirel'in artık aşırı sağ ve solun ortaya çıkardığ 1 anarşiyi ortadan kaldıramayacağına dair endişeler yükselişe geçmiştir.

Anlaşılan o ki, 1969 Genel Seçimleri'nden sonra Türkiye'yi yönetmeye başlayan Hükümet, zayıf bir hükümettir. Hükümet partisi AP, parti içi muhalefet sonucu bölünmüş ve Başbakan ise itibar kaybetmiştir. Sistemden beklediğini bulamayan muhalif partiler de hükümetle uzlaşacak bir durumda değildir. Buna paralel olarak, 1970 yılı ekonominin bozulduğu ve büyük bir

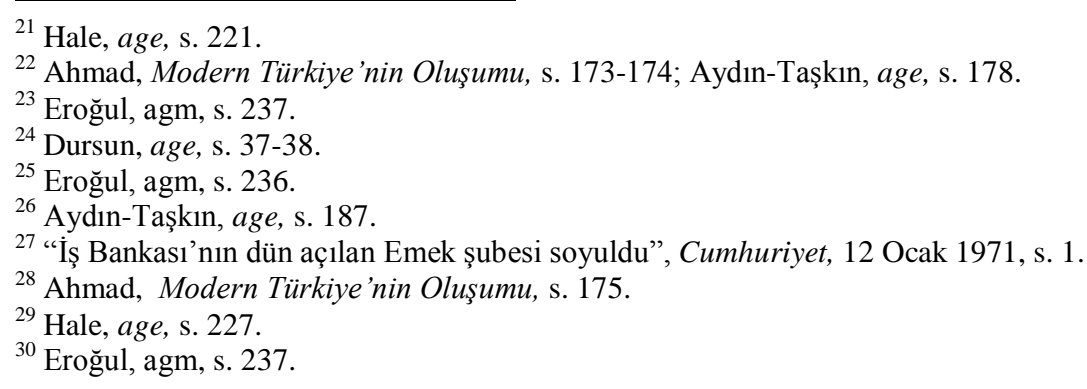


ekonomik krizin ortaya çıktığı bir yıl olmuştur. ${ }^{31}$ İktidarın bütün sorunları çözemeyeceğine dair kanının güçlenmesi karşısında 1970 yılının başlarından itibaren askeri müdahale ve darbe alternatifleri gündeme gelmeye başlamıştır. Ülkede devam eden bunalımın görüşüldüğü Milli Güvenlik Kurulu toplantılarında ön plana çıkan Muhsin Batur, bu alternatifleri dile getirmiştir. 1971 yılının başlarına gelindiğinde ise ordu içinde artık müdahale yöntemleri tartışılmaya ve bunun için hazırlıklar yapılmaya da başlanmıştır. ${ }^{32}$

Ülkedeki bunalım karşısında bir askeri müdahalenin ciddi bir biçimde konuşulduğu sırada siyasilerden ve sivil toplum örgütlerinden devletin başı olan Cumhurbaşkanlığı kurumuna bunalımdan çıkmak adına bir öneri ve şikâyet başvurusunun yapılıp yapılmadığı merak konusudur. Bu merak, yapılan bu çalışmayla giderilmeye çalışılacağı gibi aynı zamanda gelen başvuruların içeriğine bakılarak başvuranların bunalım karşısındaki tutum ve davranışları incelemeye çalışılacaktır. Bununla birlikte bunalımın boyutu gözler önüne serilecektir. Önerilerin, ne düzeyde etkili olduğu ve Cumhurbaşkanlığınca uygulanıp uygulanmadığ 1 da tartışılacaktır.

\section{Siyasi Partilerden Gelen Şikâyet ve Öneriler}

Ülkede kamu düzenin bozulduğu ve bir askeri müdahalenin beklendiği esnada bazı siyasi partilerden Cumhurbaşkanı Cevdet Sunay'a yazılı olarak şikâyet, uyarı ve öneriler gelmiştir. Bunlar, daha ziyade o partilerin yaşanan süreçle ilgili kendi siyasi görüşlerini içermektedir. 12 Mart Müdahalesi'ne giden süreçte yaşananlara sesiz kalmak istemeyenler böylece tavır ve tutumlarını da ortaya koymuşlardır.

17 Ekim 1966 tarihinde kurulan ${ }^{33}$ ve kurucularının çoğunluğunu Alevilerin oluşturduğu Birlik Partisi (BP) ${ }^{34}$ içinde bulunulan genel durum hakkında görüşlerini ve bu bunalımdan çıkmak için düşündükleri önerilerini 8 Ocak 1971 tarihinde yazılı olarak Cumhurbaşkanı'na sunan partilerden sadece birisiydi. ${ }^{35}$ BP, en son yapılan 1969 Genel Seçimleri'nde sadece 8 milletvekili çıkartabilmişs ${ }^{36}$ küçük bir partidir. Genel Başkan Sivas Milletvekili Mustafa Timisi'nin imzasını taşıyan yazıda partiye göre, öncelikle öğrenci ve işçi hareketleri birer sosyal bunalımdır. Bu hareketlerin esas gerekçesi, o güne kadar takip edilen kalkınma politikasının ülkenin ekonomik, sosyal ve kültürel yapısına uymamasıdır. Meseleye bu açıdan bakılmalıdır. Bu hareketler, milli güvenlik ve bütünlüğ̈̈ bozmaya yöneltilmiş bir hareket olarak nitelememek gerekmektedir. Öğrenci ve işçi hareketlerinin esas kökeninde ayrıca yaşanan başka olumsuz olaylar da vardır. Anadolu'nun bütünlüğünü bozan gerici ve irticai hareketlerin desteklenip teşvik edilmesi, modern olmayan eğitim sistemlerinin sürdürülmesi, Atatürk inkılaplarının inkar ve ihlal edilme çabaları, toplu namaz mitingleri, Atatürkçü gençliğe karş1 “milliyetçi süsü" verilerek "besleme bir gençlik grubunun” çıkarılması, iktidarını kaybetmemek adına hükümetin her çeşit tekniği deneyerek Meclis’ten milletvekili kapmaya çalışması sosyal bunalıma (öğrenci ve işçi hareketleri) neden olmuştur. Ayrıca 1961

\footnotetext{
${ }^{31}$ Ahmad, Demokrasi Sürecinde Türkiye, s. 256-257.

${ }^{32}$ Geniş bilgi için bkz. Dursun, age., s. 42-47.

33 "Yeni bir siyasi parti kuruldu: "Birlik Partisi", Cumhuriyet, 18 Ekim 1966, s. 1.

34 Kurulduğu gün yaptıkları basın açıklamasında Parti, "İlerici, devrimci, reformcu, Türkçü ve Atatürkçü", olduklarını ifade ederek "Aşırı sağın ve solun, gericiliğin, ayırıcılık ve bölücülüğün karşısında" yer alacaklarını aktarmıştır. Partilerinin amaçlarını da kısaca şöyle belirtmişlerdir: "Türkçe'nin yurdumuzda hakim kılınması, ibadet dilinin, din eğitiminin Türkçe yapılması; dış ticaret, bankacılık ve sigortacılık ile petrol ve madenlerin devletleştirilmesi, özel sektörle kamu sektör arasindaki çizginin devlet tarafindan tespit edilmesi". Ali Haydar Soysüren, Türkiye Birlik Partisi'nin Kuruluşu ve Faaliyetleri (1966-1980), (Marmara Üniversitesi Türkiyat Araştırmaları Enstitüsü, Yayımlanmamış Doktora Tezi), İstanbul 2014, s. 114.

${ }^{35}$ Cumhurbaşkanlığ Cevdet Sunay Arşivi (CCSA), Yer No: 5/6-19; Fihrist No: 7781-48.

${ }^{36}$ Çavdar, age, s. 160.
} 
Anayasası'nın ön gördüğü köklü, sosyal ve ekonomik reformların aradan 10 yıl geçmiş olmasına rağmen hayata geçirilmemiş olduğu ve halkın gerçek temsilcilerinin seçilmesini önlemek maksadıyla seçim kanunlarıla "biçimsel bir demokrasi oyununa devam edildiği" iddia edilerek ${ }^{37}$ isim vermeden Hükümet, sosyal bunalımdan dolayı suçlanmıştır.

Aktarılmış olunan bu sorunların hemen halledilemeyecek ciddi sorunlar olduğu belirtilerek, ${ }^{38}$ "tekliflerimiz" başlı̆g 1 altında bunalımdan çıkmak adına 3 maddelik bir teklif sunulmuştur. Birinci maddeye ülkede devam eden olayların gerekçesi sosyal, kültürel ve ekonomik koşulların bozukluğu yani geri kalmışlı̆̆ gösterilerek başlanmıştır. Geri kalmışlığının tek nedeni olarak da o güne kadar ülkeyi yönetmiş siyasi iktidarların ülkenin gerçeklerine uymayan yanlış politikalar gütmeleri gösterilmiştir. 1961 Anayasası'na rağmen de bir değişiklik meydana gelmemiştir. Olaylara bu açıdan bakılması gerektiği söylenmiş ve ardından "bir Polis Devleti zihniyetini terk edip, sosyal Devlet kavramı ve anlayışı içinde bir siyasal iktidarın demokratik yoldan iş başına getirilmesi şartlarını araştırıp hazırlanması" gerekliliği birinci teklif olarak sunulmuştur. İkinci teklifte de toplumun her kesimin temsilini sağlamak adına seçim sisteminin değiştirilerek Ekim 1971 kısmı senato seçimleriyle birlikte genel seçimlere gidilmesi dile getirilmiştir. Bu işleri yapabilecek şaibeden uzak güvenilir bir hükümetin kurulması da üçüncü teklif olarak hemen öne sürülmüştür. ${ }^{39}$

Cumhurbaşkanlığına aynı gerekçelerden dolayı başvuruda bulunan bir diğer siyasi parti ise Büyük Anadolu Partisi (BAP) ve onun Genel Başkanı Ahmet Mithat Aslan'dır. ${ }^{40} 1969$ Genel Seçimleri'ne bile katılmamış olan bu küçük partinin ${ }^{41}$ Genel Başkanı hakkında Cumhurbaşkanlığı'na bir istihbarat raporu iletilmiştir. İletilen rapora göre, Aslan, Baasçı eğilimleri üzerinde barındıran bir İslam sosyalistidir. Varlıklı ve dört dil bilmekte olup İsviçre'de öğrencilik yıllarında İslam öğrencilerinin kurduğu bir teşkilatta çalışmıştır. 1963 yılından önce İslam öğrencilerinin adayı olarak Lozan Üniversitesi Talebe Birliği Genel Sekreterliği'ne seçilmiştir. 1969 Genel Seçimleri'nden önce de Pakistan muhalefet lideri Butto ile görüşmüştür. Aynı zamanda görüştüğü bazı kuvvetli şahıslar O'na Türkiye'de İslamcı sosyalist bir parti kurması halinde maddi yardım yapabileceklerini söylemiştir. Siyasi görüşmelerine devam eden Aslan, 3 Kasım 1970 tarihinde bu sefer de İstanbul'da Suriye Başkonsolosu Nizar El Cundi ile irtibata geçmiş ve partisini Suriye'deki Baas Partisi paralelinde bir parti haline getirmek istediğini söyleyerek bu konuda maddi, manevi yardım talebinde bulunmuştur. Ayrıca Nasyonel Sosyalizmi benimsemiş İzmir Selçuk Kartalı Derneği ile dirsek teması içerisinde olan Aslan, bu derneğin üyelerini Filistin Gerilla Teşkilatı'nda eğitilmeleri adına yurt dışına çıkarmayı planlamıştır. Aslan hakkındaki son iddia ise, diktatörlüğe dayalı bir rejim kurmak için ihtilal yapma düşüncesinde olan İzmir Selçuk Kartalı Derneği ile birlikte çalışarak ordu alt kademelerine sızmaya çalıştı̆̆ 1 şeklindedir. ${ }^{42}$

İşte hakkında çeşitli iddiaların bulunduğu BAP Genel Başkanı Ahmet Mithat Aslan, 4 Ocak 1971 tarihinde Cumhurbaşkanı'na çektiği bir telgrafta parti olarak ortaya çıkan bunalımdan rejim adına kaygı duyduklarını belirttikten sonra gelinen nokta nedeniyle AP'yi sorumlu tutmuştur. AP, Anayasa'nın ön gördüğü köklü reformları aczi ve basiretsizliği nedeniyle başaramamış, bu yüzden de Türkiye, bu "sevimsiz atmosfer" ile karşı karşıya kalmıştır. Gerekli tedbir olarak da derhal milli bir koalisyonla seçimlere gidilmesini ve sorunları konuşup halletmek üzere bütün siyasi genel başkanlarının Cumhurbaşkanın başkanlığındaki bir yuvarlak

${ }^{37}$ CCSA, Yer No: 5/6-19; Fihrist No: 7781-48.

${ }^{38}$ Ayn1 yer.

${ }^{39}$ CCSA, Yer No: 5/6-19; Fihrist No: 7781-49.

${ }^{40}$ CCSA, Yer No: 5/6-19; Fihrist No: 7781-72.

${ }^{41}$ Çavdar, age, s. 160-161.

${ }^{42}$ CCSA, Yer No: 5/6-19; Fihrist No: 7781-73, 74. 
masada toplanmasını önermiştir. ${ }^{43}$ Anlaşılacağı üzere, BAP da BP gibi ortaya çıkan bunalımdan Hükümet'i ve Hükümet partisi AP'yi sorumlu tutmuştur. Tıpkı BP gibi bu Parti de erken genel seçimlerin yapılmasını bir öneri olarak sunmuştur.

$\mathrm{Bu}$ telgrafin çekilmesinden altı gün sonra bu sefer yine aynı Parti, bir yazı ile Cumhurbaşkanlığı'na başvurarak bunalımdan çıkış için yine kendilerinin görüşlerinin neler olduğunu iletecektir.

BAP Genel Yönetim Kurulu, 2 Ocak 1971 tarihinde toplanarak bir yazı kaleme almışlardır. Altında Genel Başkan Ahmet Mithat Aslan'ın imzasının yer aldığı yazıda parti olarak kendileri de içinde bulunulan bunalım nedeniyle üzüntü ve endişe içerisindedirler. Bunalımın başlıca sebebi olarak da yine Hükümet'in aczi ve yetersiz oluşu ve zamanın gereklerine göre gerekli reformları yapmaması ve tedbirleri almaması gösterilmiştir. Hükümet'in suçlanmasından sonra acil bir şekilde alınması gereken tedbirleri siyasal, ekonomi ve sosyal kategorilere ayırarak sıralanmıştır. Siyasi tedbir olarak AP hükümetinin çekilerek bütün partilerin iştiraki ile oluşturulacak bir milli koalisyon hükümetinin gözetimi altında derhal seçimlere gidilmesi istenmiştir. Bunun gerekçesi olarak söz konusu Hükümet'in gerçekleştirdiği şaibeli güven oylaması ile halk nazarında güvenini kaybetmiş olması gösterilmiştir.

Ekonomi tedbirleri başlığı altında ise birçok şey istenmiştir. Milli gelirin dağıtımında eşitlik sağlanmalıdır. Toprak reformu gerçekleştirilmelidir. İşçiler ve köylüler işin yerine ve kazancına ortak edilmelidir. Kredi kurumları herkesin faydalanacağı şekilde yeniden düzenlenmelidir. Varlıklı kişilerden daha fazla vergi alınmak suretiyle halk ve esnaf vergilerden muaf tutulmalıdır. Emeklilik çağında gelmiş olan vatandaşa ise emekli maaşı bağlanmalıdır. ${ }^{44}$

Son olarak sosyal tedbirler konusunda da ilginç konulara temas edildiği görülmektedir. Öncelikle din kurumlarına önem verilmesini sağlayacak bir anayasa değişikliği yapılmalıdır. Bütün öğretim merkezlerinde diğer dersler gibi din eğitimine ve kültürüne fazlasıyla önem verilmeli, din dersleri zorunlu hale getirilmelidir. Ardından ahlaken inançlı yüksek karakterli bir neslin yetiştirilmesi için de uğraşılmalıdır. Eğitimin milli olmasının sağlanması ve okumak isteyen fakirlere okuma imkânlarının nakledilmesi tedbir olarak Cumhurbaşkanlığı makamına sunulmuştur. ${ }^{45}$ Görüldüğü üzere, BAP'ın sosyal ve ekonomik başlıkları altında sunduğu öneriler, aynı zamanda ülkenin tekrar bir daha bunalıma düşmesini engellemeye yönelik önerilerdir.

Cumhurbaşkanlığı'na gelen şikâyet, uyarı ve önerileri içeren bir yazı da Turhan Feyzioğlu'nun genel başkanlığını yaptığı Güven Partisi’nden gelmiştir. ${ }^{46}$ Güven Partisi 12 Mayıs 1967 tarihinde ortanın soluna karşı çıkan CHP içindeki "Göbekçiler" adı verilen 48 milletvekilinin CHP'den istifa etmesiyle kurulmuştu. Parti'nin genel başkanlığına da Turhan Feyzioğlu seçilmişti. ${ }^{47}$ Kuruluşundan iki yıl sonra yapılan 1969 Genel Seçimleri'nde ise Güven Partisi, \% 6,6 oy alarak, 15 milletvekili çıkartabilmişti. ${ }^{48} 1971$ yılının başlarında ülkedeki anarşinin had safhaya ulaştığı bir sırada Feyzioğlu, Cumhurbaşkanı Cevdet Sunay ile görüşerek ülkenin içerisinde bulunduğu durumu kendi açısından resmetmekle birlikte o noktaya gelinmesinde nelerin etkili olduğu konusunda bazı teşhislerde bulunmuştur. Bunu yaparken de

\footnotetext{
${ }^{43}$ CCSA, Yer No: 5/6-19; Fihrist No: 7781-72.

${ }^{44}$ CCSA, Yer No: 5/6-19; Fihrist No: 7781-75.

${ }^{45}$ CCSA, Yer No: 5/6-19; Fihrist No: 7781-76.

${ }^{46}$ CCSA, Yer No: 5/6-19; Fihrist No: 7781-55.

${ }^{47}$ Atakan Hatipoğlu, CHP'nin İdeolojik Dönüşümü: Kemalizmden Sosyal Demokrasiye, 2. Basım, Kaynak Yayınları, İstanbul 2012, s. 250, 252; "Güven Partisi kuruldu”, Milliyet, 13 Mayıs 1967, s. 1, 7.

${ }^{48}$ Suna Kili, 1960-1975 Döneminde Cumhuriyet Halk Partisinde Gelişmeler-Siyaset Bilimi Açısından Bir İnceleme-, Boğaziçi Üniversitesi Yayınları, İstanbul 1976, s. 250.
} 
kimlerin hatası ve kusuru olduğunu da kaydetmiştir. Alınması gereken tedbirleri ise partisinin bir teklifi olarak da Cumhurbaşkanı'na sunmuştur.

7 Ocak 1971 tarihinde Turhan Feyzioğlu tarafindan Cumhurbaşkanı'na şifahen sunulan bilgiler, yazılı hale getirilmiştir. Yazıda, Türkiye'de yasak olmasına rağmen sınıf kavgası tahrikçiliğinin yapıldığı belirtilerek bu durum şikâyet edilmiştir. Ayrıca şikâyet edilen konular arasında 1rkçılığa dayalı bölücü, yıkıcı ve irticai faaliyetlerin yapılması da vardır. $\mathrm{Bu}$ faaliyetlerin bir kısmının nerede yapıldığ 1 konusunda ise adres gösterilmiştir: "Kışkırtmalar, resmi binaların çatısı altında, kürsülerde, bildirilerde, Devlet binalarının duvarlarına asılan afişlerde, aşırı soldaki bir parti liderinin basın toplantısında açıktan açı̆̆a yapılabilmektedir”. Dışarıdaki askeri ve siyasi değişmelere de dikkat çekilerek iç bünyede çok sağlam ve son derece uyanık olunması gerektiği ifade edilmiştir. İçeride ise iki tür tehlike bulunmaktadır. Bunlar, Moskovacı veya Pekinci bir komünist dikta rejiminin kurulması için çalışanlar ile irticai faaliyetlerde bulunanlardır. Bu tehlikelerden birisini görüp diğerini görmemek ise gerçeğin bir kısmını gözden kaçırmak olur. ${ }^{49}$

Üniversitelerdeki manzara da şikâyet edilen konulardan birisidir. Gerçek milliyetçi, Atatürkçü, haysiyet sahibi çok sayıda öğretim üyesi ve öğrencilerin, y1llarca devam eden ihmallerin sonucunda ortaya çıkan aşırılıkların ve zorbalıkların baskısı altında olduğu belirtilmiştir. Okumak isteyen birçok üniversite öğrencisi okullara silah tehdidiyle sokulmamaktadır. Yurtlar ve devlet laboratuvarları silah cephesi haline getirilmiş olunup devlet binalarının duvarları "yıkıcı faaliyetlerin ilan tahtası" haline sokulmuştur. Üniversite kampüslerinde silah talimleri yaptırılarak hakkında yakalama kararı olanlar devlet yurtlarında barındırılmak suretiyle devletin otoritesi içe sayılmıştır. Parasız dağıtılan yayınlarla da serbest bir şekilde "hiçbir hukuk ve ahlak sınırı tanımayan yıkıcı propagandalar" yürütülmektedir. Kısacası sokaklardan üniversitelere, fabrikalara kadar her yerde kanun hâkimiyeti yerine kaba kuvvet hâkimiyetini kurmak isteyen "huzur ve hürriyet düşmanları" hareket halindedir. ${ }^{50}$

Yaşanan ve yaşanmakta olan olaylardan dolayı Başbakan Demirel'in vurdumduymaz hareket ettiği iddia edilerek Demirel, suçlanmıştır. Demirel, olaylar karşısında "bu olaylar mahallidir, basit zabıta vakalarıdır, birkaç büyük şehrimize münhasırdır, demokrasilerde biraz da anarşi vardır, her memlekette böyle olaylar olmaktadır, bu olaylar hürriyetin icabıdır, bunlara alışacaksınız" şeklinde tehlikeleri küçümseyen beyanlarda bulunmuştur. Arkasından, yazıda "Hiç şüphesiz, devlet idaresinde sorumluluk alan insanların, olaylar karşısında serinkanlılıklarını, muhakeme ve karar güçlerini muhafaza etmeleri ve halku sebepsiz telaş ve endişeye düşürmemeleri" gerektiği ifade edilerek ancak bunun ülkede yaşanan vahim olaylar karşısında böyle davranmanın soğukkanlılık kavramıyla hiçbir ilgisinin olmadığı anlatılmıştır. İşte Hükümet'in olaylar karşısında kayıtsız kalması ve teşhiste hata etmesi Türkiye'nin bunalıma düşmesinde etkili olmuştur. Bunun yanında yıkıcı faaliyetleri zamanında teşhis edemeyerek bunları desteklemiş olan solcu muhalefetin de payı vardır. Bu noktadan sonra yazıda, Başbakan'ın sorumlu mevkide bulunmasına rağmen kendisinden başka herkesi ve Anayasa kurumlarını sorumlu, kusurlu tuttuğu iddia edilmiştir. Başbakan'ın bu şekilde davranarak sorumsuzluğunu ortaya koymaya çalışması sert bir dille eleştirilmiştir. Hükümet'in siyasi ve hukuki bakımdan yeteri kadar görev ve yetkisinin olduğu belirtilmiştir. Fakat Hükümet, bu görev ve yetkilerini bilgiyle, inançla, ciddiyetle ve etkili bir şekilde kullanmamıştır. Bu da istenen sonucu vermemiştir. Durum böyle iken Başbakan ve ekibinin kendisine yeni yetkiler verilmesi halinde sorunları çözeceğini iddia etmesi de gerçekçi değildir.

\footnotetext{
${ }^{49}$ CCSA, Yer No: 5/6-19; Fihrist No: 7781-55, s. 1-2.

${ }^{50}$ CCSA, Yer No: 5/6-19; Fihrist No: 7781-55, s. 2-4.
} 
Çünkü zayıf, iradesiz ve kararsız bir tutumla hareket eden Hükümet, fayda sağlayacağı yerde yeni direnişleri tahrik bile edebilir. ${ }^{51}$

Başbakan, devlet otoritesini korumak adına gevşek ve inançsız bir şekilde yaptığ faaliyetler nedeniyle yıpranmıştır. Başka nedenlerden dolayı da Başbakan'ın itibarını kaybettiği aktarılarak mevcut Başbakan ile yıkıcı faaliyetlerle tesirli bir şekilde mücadele edilemeyeceği anlatılmıştır. Buhrandan demokratik usullerle çıkılabileceği hatırlatılarak bunun için itibarlı ve güçlü bir hükümete ihtiyaç olduğu dile getirilmiştir. Bunun için de iktidar partisi AP, derhal kendi içerisinden yıpranmamış bir başbakan adayı çıkartmalıdır. Başka bir başbakanın liderliğinde kurulacak hükümetin, daha geniş bir tabana yayılmasının da faydalı olabileceği öneriler arasındadır. Yani bir milli hükümetin kurulması ile hem anarşiye hem de toplumun sorunlarına karş1 etkili mücadele edilebileceği ileri sürülmüştür. ${ }^{52}$

Ülkenin karşı karşıya bulunduğu meseleleri önemsediğini sık sık tekrar eden Feyzioğlu, DİSK ve ona bağlı kuruluşları çalışma hayatında sınıf kavgasını yaymakla suçlamıştır. Aşırı militanların devletin çeşitli kurumlarına sızdığını, laik devlete ve cumhuriyete inanmayan istismarcıların faaliyetlerini hızlandırdığını ve çeşitli meslek gruplarında devletin otoritesini tanımama eğiliminin arttığını bir kez daha dile getiren Feyzioğlu, Başbakan'ın halen bunlardan habersiz ve meselelere doğru teşhis koymadığından dert yanmıştır. Diğer yandan komünizmin sandıktan çıkmadığını; kurum, kuruluş ve şahıslara sızarak egemenliklerini kurduğunu haber vererek bu anlamda bir somut örnek vermiştir. Bir komünist liderinin sözlerine atıfta bulunarak üç bin kişilik bir "çelik çekirdeğin" Türkiye'yi kızıl ihtilale sürüklemeye yetebileceğini aktarmıştır.

Feyzioğlu, sözlerinin sonlarına doğru iç buhranı önlemek adına öne sürdüğü milli hükümet kurma meselesine yeniden değinerek bu sefer geniş tabana dayalı bir koalisyon hükümetinin de bunun için kurulabileceğini anlatmıştır. Fakat nasıl bir hükümet kurulursa kurulsun yıpranmış bir başbakanın başkanlığı altında kurulacak hükümetin hiçbir fayda sağlayamayacağını iddia etmiştir. Yani Başbakan Süleyman Demirel, kurulması istenen hükümetin başına getirilmemelidir. Aksi takdirde başarı anlamında sonuç değişmeyecektir. ${ }^{53}$

Hemen acil alınması gereken tedbirler anlamında da Feyzioğlu sözlerini şu anlamlı sözlerle bitirmiştir: "Anarşiye ve ylkıcı faaliyetlere karşı tesirli şekilde mücadele etmek, iktisadi alandan kanun uygulaması alanına kadar gerekli bütün tedbirleri süratle ve azimle uygulamak, güven ve huzuru yeniden tesis etmek için kaybedilecek vakit kalmadığ inancındaylz. Geç kalmak çok geç kalmak olacaktır”. ${ }^{4}$ Anlaşılacağ 1 üzere, Güven Partisi, BP gibi öğrenci ve işçi hareketlerine hoşgörü ile bakmamıştır. Güven Partisi, BAP'tan farklı olarak komünizmin yanı sıra irtica tehlikesinden de söz ederek Cumhurbaşkanı'nın dikkatini irtica tehlikesine de çekmeye çalışmıştır. Her üç siyasi partinin (BAP, BP, GP) ortak görüşü bunalım sorumlusunun mevcut AP Hükümeti'nin olduğu yönündedir. Dolayısıyla bir zorunluluk olarak demokratik yollardan hükümetin değişmesi gerektiği savunulmuştur. Diğer iki partiden farklı olarak GP, sorunların çözümü noktasında Anayasa'nın ön gördüğü reformların yapılması gerekliliğinden söz etmemiştir. Şunu da ifade etmek gerekir ki, Güven Partisi'nin bunalımdan dolayı hükümetin yanı sıra sol muhalefeti suçlaması da dikkatlerden kaçmamaktadır.

Öte yandan her üç siyasi partinin ortak önerisi olan Demirel'in ve Hükümeti'nin demokratik yollarla değişmesi gerektiği önerisi yerine getirilememiştir. Ne yazık ki 12 Mart askeri

${ }^{51}$ CCSA, Yer No: 5/6-19; Fihrist No: 7781-55, s. 4-7.

${ }^{52}$ CCSA, Yer No: 5/6-19; Fihrist No: 7781-55, s. 8-9.

${ }^{53}$ CCSA, Yer No: 5/6-19; Fihrist No: 7781-55, s. 9-10.

${ }^{54}$ CCSA, Yer No: 5/6-19; Fihrist No: 7781-55, s. 11. 
müdahalesi ile bu öneriler, demokratik olmayan yollardan zor kullanarak yerine gerçekleştirilmiştir. 12 Mart 1971 tarihinde verilen Muhtıra'nın birinci maddesinde gelinen noktada parlamentonun yanında AP Hükümeti de sorumlu tutulmuş ve çözüm olarak da öncelikle kuvvetli ve inandırıcı bir hükümetin teșkil edilmesi istenmiștir. Bunun gerçekleşmemesi halinde ise doğrudan doğruya yönetime el konulacağı tehdidi yapılmıştır. ${ }^{55}$ Gerçekten de Başbakan Süleyman Demirel, hemen istifa etmiştir. ${ }^{56}$ Ardından partisinden ayrılan CHP'li Nihat Erim, Cumhurbaşkanı Sunay tarafından partiler üstü bir hükümet kurmakla görevlendirilmiştir. ${ }^{57} \mathrm{Bu}$ da göstermektedir ki, 12 Mart Müdahalesi öncesinde Cumhurbaşkanlığı'na gelen öneriler tam olarak etkili olmamıştır. Demokrasi işletilememiştir.

\section{Millet Meclisi Üyelerinden ve Senatörlerden Gelen Şikâyet ve Öneriler}

12 Mart Müdahalesi'ne giden yolda çeşitli siyasi partilerin dışında bazı Meclis üyeleri ve senatörlerden de şikâyet ve çözüm önerileri gelmiştir. Bu anlamda 5 Ocak 1971 tarihinde Cumhurbaşkanı'na hitaben Maraş bağımsız milletvekili İbrahim Öztürk ${ }^{58}$ tarafından 4 sayfalık bir mektup yazılmıştır. Öztürk, mektubunda toplumsal olayların nedenini; süratle uyanan, gelişen ve büyüyen halk kitlelerinin sosyal ekonomik meselelerine bağlamıştır. Suçu, 1961 Anayasası'na yüklemenin ise yanlış olacağı gibi hiçbir polis tedbirinin olayların üstesinden gelemeyeceğini sözlerine ilave etmiştir. Öncelikle olayların arkasındaki ana nedene bakılmalıdır. $\mathrm{O}$ ana neden ise yıllarca sosyal ve ekonomik meselelerin çözülememiş olmasıdır. 1961 Anayasası'nın emretmiş olduğu birçok reform, aradan 11 yıl geçmiş olmasına rağmen halen hiç birinin uygulanmamış olması olayların ardındaki ana nedendir. Mevcut Anayasa, değişen topluma uygun olmasına rağmen liderlerin onu uygulamaması meselenin çözümünü geciktirmektedir. $\mathrm{Bu}$ noktadan sonra liderlerde bulunması gereken özellikler meselesine değinen Öztürk, bir lideri şu şekilde tanımlamaktadır: "Toplumun ilerici ve reformcu arzularına cevap verebilen ve onun fikri ve ruhi derinliklerine inebilen kişilere lider denmiştir. Liderler, tutucu, gerici, çıkarcı unsurların çokluğuna ve örgütlerine asla değer ve taviz vermeyen ve bir yerde bu unsurlar bir kenara itip, adette az ve fakat topluma yön, aydinlık veren, dinamik, medeniyetçi reformcu unsurlara dayanan ve köklü davaları çözen kişilerdir. İktidar koltuğundan düşme pahasına da olsa, Tarihe mal olmanın tek yolu budur". Öztürk'e göre, bu özelliklere sahip Türkiye'de bir lider yoktur. Siyasi parti ve onun liderleri oy avcılığına çıkarak, bilinçsiz kitlelerin yanında yer alarak, inanmadıkları şeyleri savunmuşlardır. Atatürk devrimlerinden, özellikle de laiklik ilkesinden taviz verme yoluna gitmişlerdir. İktidara gelmek uğruna anayasa ilkelerini de bir kenara atmışlardır. İktidara gelen partiler, önceki sözlerini unutarak hareket etmişlerdir. Anayasa'da toprak, eğitim ve personel reformunun yapılması ön görülürken bunları gerçekleştirmemişlerdir. Böylece olayların patlak vermesini beklemişlerdir. Yine Öztürk'ün ifadesine göre, sıraladığı bütün bu olayların sorumlusu da siyasi partiler ve mevcut hükümettir. "Türk vatanın bă̆ımsızlı̆̆ ve halkın mutluluğu amacında birleşen Türk gençliğini”, düşman kamplara bölenler yine siyasi partilerdir. Bu partiler iktidar olabilmek için böyle hareket etmişlerdir. Hükümet de gençliğin hiçbir sorununu ele almayarak olayların çıkmasına bir yerde sebebiyet vermiştir. Siyasi partiler ve hükümetler çıkan sonuçtan suçu gençlere yüklemişlerdir. Oysa daha düne kadar bu partiler "Gençler, ülke ve dünya

\footnotetext{
55 “Ordu İdareye Elkoyacak”, Tercüman, 13 Mart 1971, s. 1.

56 “Hükümet İstifa Etti”, Dünya, 13 Mart 1971, s. 1.

57 "Başbakan Nihat Erim", Akșam, 20 Mart 1971, s. 1, 7.

581920 doğumlu Öztürk, Siyasal Bilgiler Fakültesi ve Ankara Hukuk Fakültesi mezunudur. Sirasıyla Elvanlı Bucak Müdürlüğü, İçel ve Eskişehir İl Maiyet Memurluğu, Gediz, Çıldır, Keskin, Çankaya Kaymakamlığı, Kahramanmaraş, Van, Niğde Merkez Valiliği, Mülkiye Teftiş Heyeti Üyeliği gibi önemli kamu görevlerini icra etmiștir. Kahramanmaraș Belediye Bașkanlığından sonra 14. Dönem Kahramanmaraș milletvekili seçilmiștir. TBMM Albümü 1920-2010, Cilt 2: 1950-1980, Basım:2, TBMM Basın ve Halkla İlişkiler Müdürlügü Yayınları No:1, Ankara 2010, s. 942.
} 
sorunları ile uğraşmalıdırlar" demekteydiler. Gençliğin kendi ellerinden kaydığını görünce de bu sefer gençlerin önce okullarını okuması gerektiği savunmaya başlanmıştır. ${ }^{59}$

Yine Öztürk'e göre, eğer siyasi partiler ve hükümetler oy ve iktidar avc1lığı yerine gençliği ve tüm toplumu, bütün kesimleriyle ele alıp bilimsel yöntemlerle sorunları çözmeye çalışmış olsa idi bugünkü huzursuzluklar meydana gelmezdi. Şimdilerde "böl ve vurdur" politikasının toplumun her kesimine sirayet ettirilmiş olduğunu söyleyerek, Türk-İ̧s’e karş1 DİSK, TÖS'e karşı MÖD, Dev-Genç'e karşı Ülkü Ocakları'nın çıkartıldığını iddia etmiştir. Demokrasilerde karşıt fikirlerin bir arada olmasına rağmen Türkiye'de partilerin dışında, fakat onların yönetiminde kurulan ideolojik oluşumlar kendi amaçlarını aşıp, sağ-sol mücadelesine sürüklenmekte ve birbirlerini vurmaktadırlar. ${ }^{60}$

O, şehirlerden sonra en büyük oy deposu olarak görülen köylere sıranın geldiğini belirterek politikacıların er geç burayı da bölüp köylüleri birbirine vurduracağını iddia etmiştir. Bunun belirtilerinin doğu bölgesinde ırkçı kaynaşma şeklinde ortaya çıkmakta olduğunu dikkatlere sunmuştur. ${ }^{61}$

Partiler tarafından aldatıldığııı anlayan gençlik, parlamento ve hükümetin rolüne bürünerek yaptıkları faaliyetlerle sadece kendi sorunlarına değil, tüm ülkenin sorunlarına çözüm bulmaya çalışmaktadırlar. Devlet örgütleri, siyasal teşekküller ve parlamento görevini yapmış olsaydı gençlik bu derece teşkilatlanıp birbirine düşmezdi. Ülkenin içinde bulunduğu durumdan dolayı sık sık siyasi partileri suçlamaya devam eden Öztürk, her şeyden önce siyasi partileri Anayasa çizgisinde tutmanın yerinde olacağını dile getirmiştir: “Atatürk'ün laik Meclisinde 'Cennetmekân Abdülhamit han' diye konuşabilen, gençleri kuytu ormanlarda komanda adı altında yetiştiren, 40.000 cami ve mescidi politika ocağ inhisarına alan ve sirasi geldikçe taviz veren siyasi partiler, Anayasaya uymaya kesinlikle davet edilmelidir". Siyasi partilerin Anayasa çizgisine çekilmesini bir çözüm mahiyetinde teklif olarak sunmanın yanında seçim sisteminin değiştirilmesini de dile getirmiştir. Öztürk'ün bunun yanında başka bir teklifi daha vardır. Demirel iktidarı eylemleriyle bütün devrimci ve Atatürkçü kuruluşların karşısında durmaktadır. Onlar da iktidarda olmanın coşkunluğu ve gururuyla bu kurumların karşısında yer almaktadırlar. Kurumlara karşı başarıya ulaşamayan Hükümet, halk kitlelerini onların üzerine salmaktadır. Diğer yandan Hükümet ve onun baş1 Demirel türlü şaibeler nedeniyle aşınmış durumdadır. Hiçbir kimse ve hiçbir teşekkül de bu Hükümet'in görevde kalmasını istememektedir. Bu analizden sonra Öztürk, başlıca bir çözüm olmasa bile zaman kazanmak ve tansiyonu düşürmek için Başbakan'ın görevden alınmasını ve onun yerine kişiliğine inanılır tarafsız bir şahsiyetin etrafında milli bir hükümetin kurulmasını teklif etmiştir. Böyle bir hükümet de tarafsız ve güvenilir davranışlarıyla ülkede hızlı bir şekilde huzuru sağlayacak ve Anayasa'nın gösterdiği reformları yerine getirecektir. ${ }^{62}$ Öztürk'ün çözüm olarak öne sürdügü Başbakan ve hükümet yukarıda da ifade edildiği üzere, 12 Mart Muhtırası'nın verilmesinden hemen sonra kurulacaktır. CHP'den istifa ettirilen Nihat Erim, tarifi yapılan hükümeti kurmuştur.

Dikkat edilecek olunursa İbrahim Öztürk, olayların o raddeye gelmesinden sadece Hükümet'i değil, bununla birlikte Devlet örgütlerini, siyasi partileri ve parlamentoyu da sorumlu tutmuştur. Oysa Cumhurbaşkanı'na gelen diğer yazıların hiç birisinde bu denli geniş tabanlı bir suçlama yoktur. Dolayısıyla Öztürk'ün bu mektubu farklı bir nitelik taşımaktadır.

${ }^{59}$ CCSA, Yer No: 5/6-19; Fihrist No: 7781-28, s. 1-2.

${ }^{60}$ CCSA, Yer No: 5/6-19; Fihrist No: 7781-28, s. 2.

${ }^{61}$ CCSA, Yer No: 5/6-19; Fihrist No: 7781-28, s. 3.

${ }^{62}$ CCSA, Yer No: 5/6-19; Fihrist No: 7781-28, s. 3-4. 
Ülkede var olan bunalımı giderme anlamında Cumhurbaşkanlığı'na gelen önerilerden bir tanesi diğerlerinden daha farklı bir özellik taşımaktaydı. Cumhuriyet Senatosu Kontenjan Grup Başkanlığı tarafından 8 Ocak 1971 tarihinde gönderilen yazıda bunalımın çözüm adresi olarak demokratik kurumlar değil de ordu gösterilmiştir. ${ }^{63}$ Bu önerinin gelmesinden birkaç ay sonra ordunun, sivil yönetime müdahale etmiş olması gözlerden dikkatlerden kaçmamaktadır.

Sivas Senatörü Hüseyin Öztürk ${ }^{64}$ de bir yazı ile Cumhurbaşkanlığı'na başvurarak bunalımla ilgili şikâyet ve önerilerini bildirmiştir. Başbakan Süleyman Demirel'in irticai faaliyetlere destek verdiğini şikâyet ederek Atatürk devrimleri ve devrimci öğretmenlerin şeriatçı bir baskının altında olduğunu ileri sürmüştür. Demirel hakkındaki şikâyetlerine devam ederek O’nun ve akrabalarının kredi meselesi nedeniyle gündemde olduğunu ve konumunu kullanarak kredi meselesinin araştırılmasını engellediğini dile getirmiştir. $\mathrm{Bu}$ nedenlerden ötürü $\mathrm{O}$, Başbakan Demirel'in görevden alınmasını bir öneri olarak sunmuştur. ${ }^{65}$ Görüldüğü üzere, Hüseyin Öztürk de Maraş Milletvekili ve diğer siyasi partiler gibi olayların sorumlusu olarak Demirel'i göstermiş ve çözüm olarak da Demirel'in görevden alınmasını istemiştir. Dolayısıyla siyasiler arasında ortaya çıkan bunalımda Demirel'in sorumluluğu konusunda ortak bir konsensüsün oluştuğu ifade edilebilinir.

Zonguldak Senatörü Ahmet Demiryüce ${ }^{66}$ tarafından Cumhurbaşkanı'na çekilen 23.12.1970 tarihli telgrafta ülkedeki olaylar, "Milleti huzursuz kılan ve Türkiye Cumhuriyeti'ni ortadan kaldırmak gayesine matuf bulunan kanun tanımaz” olarak betimlemiştir. Demiryüce'ye göre, artık bu eylemlerin ciddiyeti milletin büyük çoğunluğu tarafından anlaşılmıştır. Böyle bir ortamda meseleyi halletmek adına Cumhurbaşkanı, kendi başkanlığında parti liderlerini asgari müştereklerde anlaşabilecekleri bir toplantıya çağırmalıdır. ${ }^{67}$ Demiryüce'nin de Cumhurbaşkanı'nı partiler arasında hakemlik yapmaya çağırması, sorunların kendiliğinden çözülmesini beklemenin yanlışlığını gösteren önemli bir kanıttır.

Diyarbakır Bağımsız Senatörü Selahattin Cizrelioğlu ${ }^{68}$ ile Ankara Bağımsız Senatörü Turgut Cebe'nin $^{69}$ Cumhurbaşkanı'na 9 Ocak 1971'de çektiği ortak telgrafta ise buhranın artık

\footnotetext{
${ }^{63}$ CCSA, Yer No: 5/6-19; Fihrist No: 7781-50.

64 Esas mesleği öğretmenlik olan Öztürk, senatör seçilmeden önce Milli Eğitim Bakanlığı'nda müfettişlik görevlerinde de bulunmuştur. 2 Haziran 1968 tarihinde yapılan Cumhuriyet Senatosu üçte bir yenileme seçimlerinde CHP adayı olarak Sivas üyeliğine seçilmiştir. 5 Haziran 1977 üçte bir yenileme seçimlerinde de tekrar seçilmek suretiyle üyeliğini 12 Eylül 1980 Darbesi’ne kadar devam ettirmiştir. Senato üyeliği boyunca Milli Eğitim, Kamu İktisadi Teşebbüsleri (KİT) ve Milli Eğitim Gençlik ve Spor Kültür komisyonlarında çalışmıştır. Fahri Çoker (Yayına Haz.), Türk Parlamento Tarihi Cumhuriyet Senatosu Üyelerinin Özgeçmişleri (1966-1980), C. 2, TBMM Vakfi Yayınları No; 20, Ankara 1999, s. 247-248.

${ }^{65}$ CCSA, Yer No: 5/6-19; Fihrist No: 7781.

${ }^{66}$ Hukuk mezunu olan Demiryüce, devletin çeşitli kurumlarında üst düzey bürokratik görevlerde bulunduktan sonra 2 Haziran 1968 tarihli Cumhuriyet Senatosu üçte bir yenileme seçimlerinde Adalet Partisi Zonguldak üyeliğine seçilmiştir. 5 Haziran 1977'deki üçte bir yenileme seçimlerini tekrar kazanarak senato üyeliğini 12 Eylül 1980 Darbesi'ne kadar devam ettirmiştir. Senatoda bulunduğu süre zarfında Kamu İktisadi Teşebbüsleri Komisyonu'nda üye ve Başkanvekili, Bütçe ve Plan Komisyonunda üye ve sözcü olarak çalışmıştır. Çoker, age, s. 253-254.

${ }^{67}$ CCSA, Yer No: 5/6-19; Fihrist No: 7781-11, s. 1-4.

${ }^{68}$ Paris Üniversitesi Hukuk Fakültesi'nde doktorasını yaptıktan sonra Cizrelioğlu, bir süre Diyarbakır'da serbest avukatlık yapmıştır. 1957 yılında Hürriyet Partisi'nde siyasete girmiştir. Ertesi yıl partisinin CHP ile birleşmesi ile kendisi de CHP saflarında yer almaya başlamıştır. 1964 yılında CHP'den ayrılarak Adalet Partisi'ne geçmiş olup 5 Haziran 1966 tarihinde yapılan Cumhuriyet Senatosu üçte bir yenileme seçimlerinde AP'den Diyarbakır Üyeliği'ne seçilmiştir. 15 Temmuz 1970 tarihinde partisinde istifa ederek senatörlük görevini bir süre bağımsız olarak sürdürmüştür. 25 Ekim 1973 tarihinde ise bu sefer CHP grubuna katılmış ve 12 Ekim 1975 Cumhuriyet Senatosu üçte bir yenileme seçimlerinde tekrar seçilmeyi başarmıştır. Bu görevini 12 Eylül 1980 Darbesi'ne kadar koruyan Cizrelioğlu, 1974 Ecevit Hükümeti'nde Sağlık ve Sosyal Yardım Bakanlığı görevini icra etmiştir. Çoker, age, s. 5354.
} 
tehlikeli bir noktaya ulaştığı, bunun müsebbibin de tüm otoritesini yitirmiş olan Hükümet'in yetersizliği olduğu tespitine yer verilmiştir. Cumhurbaşkanı'nın bütün bunlara rağmen böyle bir hükümetin iş başında kalmasını sağlamak adına dolaylı telkinlerde bulunmuş olması eleştirilmiş ve ardından çözüm olarak şu öneri dile getirilmiştir: "Anayasamızın ön gördüğü özgürlükleri ve demokratik parlamenter rejimi zedeleyici muhakkak olan bir takim şiddet tedbirleri yerine mevcut mevzuatla meselelere çözüm getirebilecek huzur ve asayişi sağlayabilecek milletin güvenine mazhar olabilecek ehliyetli, ciddi ve güçlü bir hükümetin iş başına gelmesini mümkün kllacak açık ve kesin bir tutum içerisine girmenizin zaruri olduğu kanısindayız". ${ }^{70}$ Yukarıda da ifade edildiği üzere, bu senatörlerin istediği böyle bir hükümet ancak 12 Mart Muhtırası'nın verilmesinden sonra kurulabilmiştir. ${ }^{71}$ Fakat, senatörler askeri bir müdahale ile değil, Cumhurbaşkanı'nın demokratik girişimiyle böyle bir hükümetin kurulmasinı arzu ediyorlard1.

\section{Sivil Toplum Örgütlerinden Gelen Şikâyet ve Öneriler}

Siyasi parti ve Meclis üyelerinin dışında sivil toplum kuruluşlarının da yaşanan bunalıma kayıtsız kalmadıkları, tutum ve önerilerini Cumhurbaşkanı ile paylaştıkları görülmektedir. Bu anlamda Tekstil İşçileri Sendikası Genel Başkanvekili Sabri Tığl1, ${ }^{72} 1971$ yılının Ocak ayında Cumhurbaşkanı'na bir telgraf çekmiştir. Tığlı, 1970 yılının millet ve toplum hayatında büyük kayıplar ve üzücü olaylar ile sona erdiğini, yeni adım atılan 1971 senesinin ise çok daha büyük olaylara gebe gözüktügünü ifade etmiştir. Cumhurbaşkanı'nın yeni yıl mesajının kendisini bu karamsar düşüncelerden bir an için uzaklaştırdığını da sözlerine ekleyerek yeni yılın yaşanabilir bir yıl olması için Hükümet'in "his ve inat yolunu" bırakıp "akll yoluna" girmesi gerekliliğine vurgu yapmıştır. Hükümet'in, yeni yılda sosyal ve iktisadi hayatı düzenleyen işsizlik sigortası, asgari ücretler, toprak ve tarım reformu gibi kanunları Meclis'ten geçirmesi gerekmektedir. O,

Volume 12

Issue 4

August

2020 bunların gerçekleştirilmesi halinde yeni yılda işçiler ve dar gelirli milyonlarca vatandaş için ülkenin yaşanabilir hale geleceğini belirtmiştir. ${ }^{73}$

Kendisini "kanun çerçevesinde, fikir yoluyla, Atatürk devrimlerini muhafaza, müdafaa, yayma gayesiyle kurulmuş, irtica ve komünizm düşmanı milli bir teşekkül" olarak tanımlayan ve 1947 y1lında kurulmuş olan Mustafa Kemal Derneği de 27 Aralık 1970 tarihinde 6 maddelik bir yazısını Cumhurbaşkanı'na sunmuşlardır. 6 maddelik yazının ilk 5 maddesi ülkenin içinde bulunduğu durumu dernek, kendi açısından yorumlamıştır. 6. maddede ise düşündükleri çareyi belirtmişlerdir. Buna göre, aşırı uçlar, gün geçtikçe milli birlik ve bütünlüğü sarsarak Atatürk ilkelerini yok etmeye, Türkiye Cumhuriyeti'ni y1kma yoluna girmişlerdir. Atatürk'ün

\footnotetext{
${ }^{69}$ 1946'da Demokrat Parti'nin kuruluşunda görev alan Felsefeci ve Kitapçı Cebe, parti yöneticileri ile anlaşmazlığa düşünce 1954 yılında partisinden ihraç edildi. 1961 yılında kurulan Adalet Partisi'nin kuruluşunda görev almış ve bu partinin 1964 yılında Ankara İl Başkanlığı görevine getirilmiş̧ir. 5 Haziran 1966 Cumhuriyet Senatosu üçte bir yenileme seçimlerinde AP adayı olarak Ankara üyeliğine seçilmiștir. 29 Nisan 1970 tarihinde partisinde istifa etmiştir, fakat 1973'te tekrar eski partisi AP'ye dahil olmuştur. AP'de fazla kalmayarak birkaç oy sonra Demokratik Parti saflarına katılmıştır. Senato görevi boyunca kendisi Milli Eğitim Komisyonu'nda üye ve Başkan, Anayasa ve Adalet Komisyonu'nda katip ve üye olarak çalışmıştır. 1975 seçimlerinde tekrar üyeliğe seçilemeyen Cebe, politikayı bırakmıştır. Çoker, age, s. 29-30.

${ }^{70}$ CCSA, Yer No: 5/6-19; Fihrist No: 7781-52, s. 1-3.

71 "Başbakan Nihat Erim", Akşam, 20 Mart 1971, s. 1, 7.

721926 doğumlu Sabri Tığlı, mesleği makine teknisyenliğidir. 1947 yılında Tekstil İş Kolu'nda sendikacılığa başlamış, Teksif Federasyonu'nun kuruculuğunu ve genel sekreterliğini yapmıştır. Ardından sırasıyla Türk-İ̧ş Konfederasyonu kurucu üyeliği ve genel yönetim üyeliği ile Tekstil İşçileri Sendikası Genel Başkanvekilliği görevlerinde bulunmuştur. Türkiye Milli Gençlik Teşkilatı Kurucu Üyeliği ve Genel Yönetim Kurulu Üyeliği de icra etmiş olan Tiğlı, 15. ve 16.dönem CHP Kastamonu Milletvekilliği yapmıştır. Esat Arslan (Yayına Haz.), Türk Parlamento Tarihi TBMM XVI. Dönem (1977-1980), C. 3, TBMM Yayınları, Ankara 2012, s. 1559.

${ }^{73}$ CCSA, Yer No: 5/6-19; Fihrist No: 7781-15.
} 
cumhuriyeti emanet ettiği gençlerin azınlık bir kısmı da sağcı-solcu diye bir birinden ayrılarak acımasız bir birlerini öldürmeye başlamışlardır. Siyasi partilerden birisi de dini siyasete alet etmeye başlamış ve bu parti büsbütün teokratik bir devlet kurmak adına faaliyet göstermektedir. Öte yandan Aşırı Sol, "Türk Halkları" sloganıyla Türk ülke ve milletini parçalamaya çalışmaktadır. Bunlar tam bağımsızlık sloganı altında Türkiye'yi yeniden "Sevr paçavrasının hudutlarına" sürüklemek niyetindedirler. Bütün bu aşır uçlar ise nihayetinde topum ve ekonomiyi alt üst ederek milli morali bozmakta ve "vatandaşı halinden muzdarip, geleceğinden endişeli kllmaktadır”. Dernek bu durum karşısında Cumhurbaşkanı'ndan bütün yetkili ve görevli organları uyarmasını, "yurdumuzun parçalanması konusunda çeşitli kaynaklardan devlet organlarınca elde edilmiş ve açıklanmasında milli sakınca görülmeyen her türlü bilgi ve belgelerin Türk kamuoyuna duyurulmasını",74 talep etmiştir. Anlaşılan o ki, Mustafa Kemal Derneği de yukarıda sözü edilen bazı partiler ve siyasiler gibi sağ-sol çatışmasının bilinçli olarak yaratıldığını iddia etmiştir. Amacın ülkeyi parçalamak olduğunu ifade eden Derneğin, isim vermeden Necmettin Erbakan'ın partisinden söz ederek irtica suçlamasında bulunması dikkatlerden kaçmamaktadır. İrtica tehlikesinin varlığından sadece bu dernek söz etmemiştir. Bu anlamda Feyzioğlu ve İbrahim Öztürk gibi kişilerden de uyarılar gelmiştir.

Sonuç olarak, sivil toplum örgütleri de içinde bulunulan bunalımdan dolayı rahatsızlık duymuşlardır. Bunalımın sorumlusu temel olarak yine Hükümet görülmüştür. Çözüm olarak Cumhurbaşkanı'nın geç kalmadan derhal hareket geçmesi önerilmiştir.

\section{Sonuç}

1970 yılının başlarından itibaren ülkedeki anarşi rejim açısından tehlikeli bir hal almaya başlamıştır. Sorunların çözülememesi nedeniyle de bir askeri darbe beklentisi ortaya çıkmışırır. $\mathrm{Bu}$ ortamdan rahatsızlık duyanlar hemen Cumhurbaşkanlığı'na başvurarak şikâyetlerini yazılı olarak dile getirmişlerdir. Bununla birlikte bunalımdan çıkmak adına çözüm önerilerini de sıralamışlardır. Başvuruda bulunanlar genel olarak küçük siyasi partiler, ismi ön plana çıkmamış Meclis üyeleri, senatörler ve sivil toplum örgütleridir. Gelen şikayetlere bakıldığında hemen hemen herkes birkaç yıldır devam eden anarşi olaylarından rahatsızlık duymakta ve bir an önce olayların sona erdirilmesini beklemektedirler. Ortaya koydukları çözüm önerileri ise, kendi siyasi düşünceleriyle genel olarak özdeş niteliktedir.

Anarşinin bu denli tehlikeli boyutlara ulaşmasından ise genelde Başbakan Demirel ve O'nun Hükümeti sorumlu tutulmuştur. Demirel 1961 Anayasası'nı uygulamadığı ve Anayasa'nın ön gördüğü reformları yapmadığı için sorunlar baş göstermiştir. Fakat bazı kişi ve partiler Demirel'in yanı sıra bütün siyasi partileri ve devletin bütün kurumlarını suçlamıştır. Diğerlerinden farklı olarak Güven Partisi ise, Demirel'in yanı sıra irticayı destekleyen partileri ve sol muhalefeti sorumlu tutma eğilimi içerisine girmiştir. Güven Partisi'nin yanı sıra irtica tehlikesinden söz eden başka siyasiler ve sivil toplum örgütleri de vardır.

Bazı kişi ve partilerin öğrenci ve gençlik hareketlerine hoşgörü ile yaklaştığı gözlerden kaçmamaktadır. Bunlar öğrenci hareketlerini suçlamak yerine daha çok Hükümeti ve siyasi partileri suçlama yoluna gitmiştir. Çünkü siyasi parti ve liderleri yaptıkları faaliyetlerle sağ-sol çatışmasının çıkmasını fitillemişlerdir.

Genel olarak anarşinin tehlikeli bir hale gelmesinden Başbakan Süleyman Demirel'in ve Hükümeti'nin yanlış uygulamalarının sorumlu tutulduğu şikâyetlerde çözüm önerisi olarak

${ }^{74}$ CCSA, Yer No: 5/6-19; Fihrist No: 7781-5, s. 1-2. 
Demirel'in demokratik yollardan Başbakanlık görevinden alınması istenmektedir. Çünkü bunlara göre, Demirel, yıpranmış bir Başbakan; Hükümet'i ise olaylar karşısında vurdumduymaz, aciz, dirayetsiz ve toplumda güvenini kaybetmiştir. Demirel'in başkanlığındaki herhangi bir hükümetin olayları sona erdiremeyeceğinin altı çizilmiştir. Önerilerin bazılarında Demirel'in görevden alınmasından sonra yerine tarafsız bir başbakanın başkanlığında milli bir hükümet kurularak erken seçimlere gidilmesi istenmiştir. Bazıları da tarafsız bir başbakanın başkanlığında milli bir hükümetin veyahut geniş tabanlı bir koalisyon hükümetinin kurulması suretiyle bütün sorunları çözebileceğini öneri olarak sunulmuştur. Kurulacak hükümet 1961 Anayasası'nın ön gördüğü reformları yerine getirerek olayların asıl kaynağını yok edebilecektir. Polis tedbirleriyle olayları sona erdirmek mümkün değildir. Gelen bazı önerilere göre de Cumhurbaşkanı'nın harekete geçerek siyasi partileri sorunları çözmek üzere bir yuvarlak masa etrafından toplaması istenmiştir. Sadece Cumhuriyet Senatosu Kontenjan Grup Başkanlığı, çözüm adresi olarak demokratik kurumları değil, orduyu göstermiştir. Diğerleri çözüm adresi olarak demokratik kurumları göstermiştir.

12 Mart Muhtırası'nda da anarşi olaylarından Meclis ve Hükümet sorumlu tutulmuş ve hükümetin değişmesi istenmişti. Bu durum, 12 Mart öncesinde Cumhurbaşkanı'na gelen önerilerle benzerlik göstermektedir. Fakat gelen önerilerin büyük çoğunluğunda bunun bir askeri darbe ile değil, demokratik kurallar içerisinde yapılması istenmiş̧i.

Gelen demokratik çözüm önerileri çok fazla etkili olmamış olacak ki 12 Mart 1971 tarihinde ordu, sivil yönetime kısmen de olsa müdahalede bulunmuştur. Oysa Cumhurbaşkanı'ndan Başbakan'ın ve hükümetin demokratik yoldan değiş̧irilmesi isteniyordu. 12 Mart'ta Başbakan Süleyman Demirel ve Hükümeti olaylardan sorumlu tutularak istifa ettirilmiştir. Yerine çözüm önerilerinde de ifade edildiği üzere, tarafsız bir başbakanın başkalığında partiler üstü geniş tabanlı bir hükümet kurulmuştur. Muhtıra'ya göre, bu hükümetin görevi anarşiyi ortadan kaldırmak ve Anayasa'nın ön gördüğü reformları yerine getirmekti. Cumhurbaşkanlığı'’na gelen önerilerin içerisinde de böyle bir hükümetin kurulmasıyla reformların yapılacağı ve bunalımdan çıkılacağından söz edilmiş olması gelen önerileri önemli kılmıştır.

\section{Kaynakça}

\section{Arşiv Belgeleri}

T.C. Cumhurbaşkanlığı Cevdet Sunay Arşivi (CCSA)

CCSA, Yer No: 5/6-19; Fihrist No: 7781-73, 74.

CCSA, Yer No: 5/6-19; Fihrist No: 7781-48.

CCSA, Yer No: 5/6-19; Fihrist No: 7781-49.

CCSA, Yer No: 5/6-19; Fihrist No: 7781-72.

CCSA, Yer No: 5/6-19; Fihrist No: 7781-75.

CCSA, Yer No: 5/6-19; Fihrist No: 7781-76.

CCSA, Yer No: 5/6-19; Fihrist No: 7781-55.

CCSA, Yer No: 5/6-19; Fihrist No: 7781-28.

CCSA, Yer No: 5/6-19; Fihrist No: 7781-50.

CCSA, Yer No: 5/6-19; Fihrist No: 7781.

CCSA, Yer No: 5/6-19; Fihrist No: 7781-11. 
CCSA, Yer No: 5/6-19; Fihrist No: 7781-52.

CCSA, Yer No: 5/6-19; Fihrist No: 7781-15.

CCSA, Yer No: 5/6-19; Fihrist No: 7781-5.

\section{Resmi Yayınlar}

ARSLAN, Esat, (Yayına Haz.), Türk Parlamento Tarihi TBMM XVI. Dönem (1977-1980), C. 3, Haz. Esat Arslan, TBMM Yayınları, Ankara 2012.

ÇOKER, Fahri, (Yayına Haz.), Türk Parlamento Tarihi Cumhuriyet Senatosu Üyelerinin Özgeçmişleri (1966-1980), C. 2, TBMM Vakfı Yayınları No; 20, Ankara 1999.

TBMM Albümü 1920-2010, Cilt 2: 1950-1980, Basım:2, TBMM Basın ve Halkla İlişkiler Müdürlüğü Yayınları No:1, Ankara 2010.

\section{Süreli Yayınlar}

Akşam

Cumhuriyet

Dünya

Milliyet

Tercüman

\section{Araştırma ve Tetkik Eserler}

AHMAD, Feroz, Demokrasi Sürecinde Türkiye (1945-1980), 4.Bask1, Hil Yayınları, İstanbul 2010.

AHMAD, Feroz, Modern Türkiye’nin Oluşumu, 9. Basım, Kaynak Yayınları, İstanbul 2011.

AYDIN, Suavi-Yüksel Taşkın, 1960 'tan Günümüze Türkiye Tarihi, İletişim Yayınları, İstanbul 2014.

ÇAVDAR, Tevfik, Türkiye'nin Demokrasi Tarihi 1950’den Günümüze, 5. Bask1, İmge Kitabevi, Ankara 2013.

ÇETINKAYA, Hikmet, 68'den 78'e Sancılı Yıllar Kuşatılmış Sokaklar, 6. Basım, Günizi Yayınc1lik, İstanbul 2006.

DURSUN, Davut, 12 Mart Darbesi: Hatıralar, Gözlemler, Düşünceler, Şehir Yayınları, İstanbul 2003.

EROĞUL, Cem, "Çok Partili Düzenin Kuruluşu: 1945-1971”, Geçiş Sürecinde Türkiye, Derleme: Irvın C. Schınk ve E. Ahmet Tonak, Baskı: 6, Belge Yayınları, İstanbul 2013, s. $173-243$.

HALE, William, Türkiye'de Ordu ve Siyaset, Çeviri: Ahmet Fethi, Alfa Yayınlar, İstanbul 2014.

HATİPOĞLU, Atakan, CHP'nin İdeolojik Dönüşümü: Kemalizmden Sosyal Demokrasiye, 2. Basım, Kaynak Yayınları, İstanbul 2012.

KİLI, Suna, 1960-1975 Döneminde Cumhuriyet Halk Partisinde Gelişmeler-Siyaset Bilimi Açısından Bir İnceleme-, Boğaziçi Üniversitesi Yayınları, İstanbul 1976. 
ÖZDEMIR, Hükmet, "Siyasi Tarih (1960-1980)", Türkiye Tarihi 4 Çağdaş Türkiye 1908-1980, Yayın Yönetmeni: Sina Akşin, 12. Basım, Cem Yayınevi, İstanbul 2013, s. 227-286.

\section{Tezler}

SOYSÜREN, Ali Haydar, Türkiye Birlik Partisi'nin Kuruluşu ve Faaliyetleri (1966-1980), (Marmara Üniversitesi Türkiyat Araştırmaları Enstitüsü, Yayımlanmamış Doktora Tezi), İstanbul 2014. 